\section{Referenties}

Armangue T et al. (20I4) Herpes simplex virus encephalitis is a trigger of brain autoimmunity. Ann Neurol, 75, 317-23.

Dalmau J et al. (2019) An update on anti-NMDA receptor encephalitis for neurologists and psychiatrists: mechanisms and models. Lancet Neurol.

Dalmau J et al. (2008) Paraneoplastic syndromes of the CNS. Lancet Neurol, 7, 327-40.

De Bruijn MAAM et al. (2019) Evaluation of seizure treatment in anti-LGI, anti-NMDAR, and anti-GABABR encephalitis. Neurology, 92, e2185-e2I96.

De Bruijn MAAM et al. (20I9) Antibodies Causing focal Epilepsy Signs and symptoms (ACES) score. A prospective, multicenter, observational cohort study. Abstract American Academy of Neurology.

Florance NR et al. (2009) Anti-N-methyl-D-aspartate receptor (NMDAR) encephalitis in children and adolescents. Ann Neurol, 66, II-8.
Graus F et al. (20I6) A clinical approach to diagnosis of autoimmune encephalitis. Lancet Neurol, I5, 39I-404.

Irani SR et al. (20II) Autoimmune epilepsies. Curr Opin

Neurol, 24, I46-53.

Lejuste F et al. (20I6) Neuroleptic intolerance in patients with anti-NMDAR encephalitis. Neurol Neuroimmunol Neuroinflamm, 3, e280.

Schmitt SE et al. (20I2) Extreme delta brush: a unique EEG pattern in adults with anti-NMDA receptor encephalitis. Neurology, 79, I094-Ioo.

Titulaer MJ et al. (2013) Treatment and prognostic factors for long-term outcome in patients with anti-NMDA receptor encephalitis: an observational cohort study. Lancet Neurol, I2, I57-65.

\title{
Genetische diagnostiek bij epilepsie
}

De kennis over genetische oorzaken van epilepsie, de mogelijkheden van genetische diagnostiek en de implicaties van een genetische diagnose nemen steeds meer toe. Deze bijdrage geeft een overzicht van de huidige stand van zaken.

Genetische testen bij epilepsie

Dankzij de implementatie van moderne technieken van DNA-onderzoek is de opbrengst van genetische diagnostiek bij patiënten met epilepsie de afgelopen vijftien jaar sterk toegenomen. De huidige diagnostiek kan de volgende testen omvatten:

- Een array analyse, waarmee wordt onderzocht of er kleine delen van een chromosoom ontbreken (deleties) of verdubbeld aanwezig zijn (duplicaties).

- Epilepsie genpanelonderzoek: onderzoek van een panel van genen voor (een bepaald type) epilepsie. Op dit moment is van enkele honderden genen bekend dat zij een rol kunnen spelen bij epilepsie.

- Exoomsequencing: onderzoek van alle ruim 20.000 genen van een persoon.

- Karyotypering: onderzoek naar het aantal en de structuur van de chromosomen.

- Onderzoek van één of enkele individuele genen.

De eerste vier onderzoeken hebben een screenend karakter en vereisen geen hypothese vooraf over de precieze genetische afwijking. Gericht onderzoek van één gen wordt alleen gedaan als er een sterk vermoeden is dat een afwijking in het betreffende gen een rol speelt.

\section{Mogelijke bevindingen}

Bij een recente meta-analyse van 20 studies naar de opbrengst van genetische diagnostiek bij patiënten met epilepsie werd met array analyse bij $8 \%$ van de patiënten een diagnose gesteld, met epilepsie genpanelonderzoek bij $23 \%$ en met exoomsequencing bij $45 \%$ (Sánchez Fernandez, et al., 2019). Deze getallen hebben betrekking op vaak wisselend geselecteerde patiënten met een indicatie voor genetische diagnostiek.

Doel van genetische diagnostiek is het aantonen van een DNA-variant die een oorzaak is van de epilepsie. Deze DNA-varianten kunnen van (één van beide) ouders zijn geërfd of bij de persoon met epilepsie nieuw (de novo) zijn ontstaan. Er kunnen echter ook andere uitkomsten zijn. Zo kunnen er DNA-varianten worden aangetoond 
waarvan niet duidelijk is of deze de oorzaak zijn van de epilepsie, of dat dit 'onschuldige' DNA-varianten zijn (VUS: Variant of Uncertain Significance). Naarmate de diagnostiek breder is en er meer genen worden geanalyseerd, wordt de kans hierop groter.

Vooral bij gebruik van exoomsequencing kunnen ook nevenbevindingen worden gedaan. Een nevenbevinding is een ziekte-veroorzakende variant die geen betrekking heeft op de epilepsie, maar wel een andere ziekte kan veroorzaken. Vanwege deze kans op nevenbevindingen wordt een volledig exoomonderzoek vooralsnog uitsluitend aangevraagd door de klinisch geneticus na pre-test counseling, terwijl array analyse en genpanelonderzoek ook veel worden aangevraagd door de (kinder)neuroloog. Als met genetische diagnostiek een verklarende afwijking of VUS wordt aangetoond dient deze door de aanvragend arts geïnterpreteerd te worden binnen de context van de klinische gegevens van de patiënt en de familiegegevens, hetgeen een specifieke expertise vergt. Veelal wordt hiervoor naar een klinisch geneticus verwezen of vindt overleg met een klinisch geneticus plaats.

\section{Indicaties voor genetische diagnostiek}

Wat zijn de indicaties voor genetische diagnostiek bij personen met epilepsie? Als personen met epilepsie (zonder een verworven oorzaak) daarnaast een ontwikkelingsachterstand/verstandelijke beperking en/of één of meer aangeboren afwijkingen hebben, is de kans op een monogene of chromosomale oorzaak groot. Genetisch onderzoek door middel van een array analyse en epilepsie genpanelonderzoek is aangewezen, hetgeen parallel of sequentieel kan worden ingezet. Als hiermee geen oorzaak wordt gevonden, kan exoomsequencing en eventuele andere genetische diagnostiek plaatsvinden door een klinisch geneticus. Afhankelijk van het laboratorium waar het DNA-onderzoek plaatsvindt omvat onderzoek van een genpanel of het exoom ook onderzoek naar deleties en duplicaties. In dat geval kan de array analyse achterwege worden gelaten.

Bij kinderen met epilepsie en een normale ontwikkeling is de indicatiestelling minder eenduidig. Hierbij is het onderscheid tussen focale epilepsie en gegeneraliseerde epilepsie van belang. De bijdrage van genetische oorzaken aan het ontstaan van focale epilepsie wordt sinds een aantal jaren in toenemende mate duidelijk. In een cohort van 40 patiënten met MRI-negatieve, focale epilepsie en tenminste één eerste- of tweedegraads familielid met koortsstuipen en/of epilepsie werd bij vijf kinderen (I3 \%) een (waarschijnlijk) ziekte-veroorzakende DNA-variant aangetoond (Perucca et al. 20I7). Er worden bij focale epilepsie relatief frequent ziekte veroorzakende varianten gevonden in de genen binnen het zogenaamde GATORI complex van de mTOR pathway: DEPDC 5 , NPRL2 en NPRL3. Hierbij kan de MRI-hersenen normaal zijn, maar ook kan een focale corticale dysplasie worden gezien. Ziekte-veroorzakende varianten in deze genen resulteren in een autosomaal dominante focale epilepsie met verminderde penetrantie (niet ieder familielid met de DNA-variant krijgt daadwerkelijk epilepsie). Naast varianten in deze genen zijn ook varianten in andere genen beschreven als oorzaak van erfelijke, focale epilepsie. (Mфller et al., 20I9) Vragen naar het voorkomen van epilepsie bij eerste- en/of tweedegraads familieleden is van belang. Is de familieanamnese positief en/of is de epilepsie therapieresistent, dan kan onderzoek van een volledig epilepsie genpanel worden aangevraagd, of van een 'subpanel' voor focale epilepsie, als dit beschikbaar is. Array analyse kan van toegevoegde waarde zijn, vooral als er naast de focale epilepsie bijkomende neurologische of psychiatrische verschijnselen zijn zoals autisme of ADHD.

Bij gegeneraliseerde epilepsie spelen genetische factoren een belangrijke rol, maar meestal in het kader van een polygene of multifactoriële etiologie. Dit wil zeggen dat de epilepsie het gevolg is van een optelsom van meerdere erfelijke en soms ook niet-erfelijke factoren. Met genetische diagnostiek wordt maar zelden een op zichzelf staande genetische oorzaak aangetoond, ook niet bij een positieve familieanamnese. Bij gegeneraliseerde epilepsie kan genetische diagnostiek zinvol zijn als:

- het verloop atypisch is; zo kan bijvoorbeeld een absenceepilepsie met atypische kenmerken een uiting zijn van het glucose transporter type I deficiëntie syndroom, een zeldzame aandoening, waarbij behandeling met het ketogeen dieet effectief is;

- er bijkomende neurologische of psychiatrische verschijnselen zijn.

\section{Geen genetische oorzaak gevonden, wat dan?}

Met de huidige genetische tests wordt een aantal typen DNA-afwijkingen niet (altijd) gedetecteerd, zoals kleine intragene deleties of duplicaties en repeatexpansies. Ook kan een DNA-variant gemist worden doordat deze slechts in een deel van de cellen aanwezig is. Dit wordt mozaïcisme genoemd. Om een mozaïek DNA-variant op te sporen kan het nodig zijn om een ander weefsel dan bloed te onderzoeken en een specifieke techniek te gebruiken (deep sequencing). Als genetische diagnostiek geen verklaring heeft opgeleverd, terwijl er wel een sterke verdenking is op een genetische etiologie, kan met een klinisch geneticus worden overlegd in hoeverre vervolgonderzoek mogelijk is.

\section{Het nut van een genetische diagnose}

Het stellen van een genetische diagnose kan consequenties hebben voor de behandeling van de epilepsie. Zo dient bijvoorbeeld bij patiënten met het Dravet-syndroom op 
basis van een SCNIA-genvariant behandeling met natriumkanaalblokkers vermeden te worden, terwijl bij patiënten met een pathogene variant in SCN2A en een aanvalsdebuut vóór de leeftijd van drie maanden natriumkanaalblokkers vaak juist effectief zijn.

Veel wetenschappelijk onderzoek op het gebied van genetische epilepsie is gericht op het definiëren of ontwikkelen van precision medicine, dat wil zeggen behandeling die is geselecteerd op basis van het onderliggende genetische defect. Hierbij kan gedacht worden aan een meer geïndividualiseerde toepassing van de op dit moment gangbare therapeutische opties, zoals behandeling met anti-epileptica, het ketogeen dieet, een nervus vagus stimulator of epilepsiechirurgie. Maar daarnaast zijn er ook nieuwe behan-delmodaliteiten in onderzoek, zoals gentherapie, waarbij genen worden vervangen of toegevoegd aan cellen, of therapie met antisense oligonucleotiden (ASO's), die aangrijpen op het RNA, het boodschappermolecuul dat ervoor zorgt dat de DNA-code wordt vertaald naar een eiwit. Op het gebied van behandeling zijn belangrijke innovaties te verwachten. Echter op dit moment is voor de meeste vormen van genetische epilepsie nog geen gerichte behandeling beschikbaar.

Dankzij een genetische diagnose is het mogelijk om een uitspraak te doen over de prognose van het verloop van de epilepsie en comorbiditeiten. De ernst van de verschijnselen van een genetisch epilepsiesyndroom kan van persoon tot persoon sterk uiteenlopen. Zo zijn er patiënten met een DEPDC5-gerelateerde focale epilepsie die slechts enkele epileptische aanvallen hebben, voor anderen kan de epilepsie ernstig zijn en gepaard gaan met een verstandelijke beperking. Dit hangt samen met het type DNA-variant, de aanwezigheid van andere, modificerende DNA-varianten, die vanaf de geboorte aanwezig zijn of in de loop van het leven zijn ontstaan, en met niet-genetische factoren zoals de ingestelde behandeling. Toch is het na een genetische diagnose vaak wel mogelijk om, binnen een bepaalde bandbreedte, een uitspraak te doen over de prognose ten aanzien van de epilepsie en de te verwachten bijwerkingen.

Als een DNA-variant als oorzaak is aangetoond, kunnen ouders en andere familieleden worden geïnformeerd over de kans om een (volgend) kind te krijgen met dezelfde genetische epilepsie. Bij een verhoogde kans kunnen zij, mede afhankelijk van de ernst van de aandoening, kiezen voor reproductieve opties als prenatale diagnostiek of pre implantatie genetische diagnostiek (PGD). Belangrijk is om hierbij te vermelden dat, ook als een bij het kind aangetoonde pathogene DNA-variant bij ouders niet is teruggevonden, voor volgende kinderen toch een herhalingskans geldt van circa I\% en er een indicatie kan zijn voor prenatale diagnostiek in een volgende zwangerschap. Een volgend kind kan opnieuw zijn aangedaan, omdat de DNA-variant bij één van de ouders slechts in een deel van zijn of haar cellen of zelfs alleen in meerdere geslachtscellen aanwezig kan zijn. De variant wordt dan met DNAonderzoek niet aangetoond, maar kan wel aan meerdere kinderen worden doorgegeven. Na een genetische diagnose dienen ouders met een kinderwens dus altijd naar een klinisch geneticus te worden verwezen! Vooral als een kind ernstige epilepsie heeft is de persoonlijke betekenis van een genetische diagnose voor ouders vaak groot. Een diagnose maakt een einde aan de zoektocht naar de oorzaak die lang en belastend kan zijn voor kind en ouders. Soms wordt gedacht dat de epilepsie het gevolg is van omstandigheden in de zwangerschap of rondom de bevalling en zijn er schuldgevoelens, die met de genetische diagnose worden weggenomen. Tot slot stelt de diagnose hen in staat om ervaringen uit te wisselen met lotgenoten.

\section{Wat brengt de toekomst?}

De afgelopen vijftien jaar is de kennis over genen die betrokken kunnen zijn bij genetische epilepsiesyndromen sterk toegenomen. De hoop en verwachting is dat er de komende jaren belangrijke ontwikkelingen op het gebied van de behandeling van deze aandoeningen zullen zijn, waarmee voor patiënten en behandelend (kinder)neurologen een nieuw tijdperk zal worden ingeluid.

\section{Referenties}

Mфller RS, Hammer TB, Rubboli G et al. (20I9) From nextgeneration sequencing to targeted treatment of nonacquired epilepsies. Expert Rev Mol Diagn; 19:217-228. Perucca P, Scheffer IE, Harvey AS et al. (2017) Real-world utility of whole exome sequencing with targeted gene analysis for focal epilepsy. Epilepsy Res; 131:1-8.

Sánchez Fernández I, Loddenkemper T, Gaínza-Lein M et al. (2019) Diagnostic yield of genetic tests in epilepsy: A meta-analysis and cost-effectiveness study. Neurology; doi: 10.1212 .

\section{SWO Midwintermeeting 'Epileptic Networks'}

\section{7 januari 2020, Amsterdam UMC, locatie AMC}

Informatie: e.a.vanvliet@uva.nl 